\title{
Israel dalam Teks-Teks Agama Islam
}

\author{
Otong Sulaeman \\ Sekolah Tinggi Filsafat Islam Sadra \\ osleman@yahoo.com
}

\section{ABSTRACT}

The Israeli-Palestinian conflict is one of the world's most hot issues of international politics. In various studies, Islam -the religion of most of Palestinians-is often seen as the root of the conflict. There are two perspectives which link Islam with the IsraeliPalestinian conflict. The first perspective believes that the conflict in Palestine is an inter-religious conflict, namely Islam versus Judaism. The second perspective sees that the conflict in the region is not an interfaith battle, but rather a battle between two entities: the invaders and the colonized. However, this second perspective still uses religion as a foundation to defend the Palestinian people because the principle of opposing the tyrant does exist in the teachings of Islam. In this article, the author will present the Qur'anic texts about Israel to analyze both perspectives. The conclusion is that the first perspective is influenced by the verses of the Qur'an that describe the Jews as a group with various bad qualities. Instead, the second perspective uses verses that describe the positive image of the Jews as a rationale.

Keywords: Al Quran, Islam, Israeli-Palestinian conflict, Jews.

\section{ABSTRAK}

Konflik Israel-Palestina adalah salah satu isu politik internasional yang paling panas di dunia. Dalam berbagai kajian, agama Islam yang dianut oleh mayoritas bangsa Palestina sering dipandang sebagai akar konflik. Ada dua perspektif di tengah internal umat Islam yang mengaitkan agama dengan konflik IsraelPalestina. Perspektif pertama meyakini bahwa konflik di Palestina adalah konflik antaragama, yaitu Islam versus Yahudi. Perspektif kedua memandang bahwa 
konflik di kawasan itu bukan pertempuran antaragama, melainkan pertempuran antardua entitas: penjajah dan terjajah. Namun, perspektif kedua ini tetap menggunakan agama sebagai landasan untuk membela bangsa Palestina karena prinsip melawan kezaliman memang ada dalam ajaran Islam. Dalam artikel ini, penulis akan mengemukakan teks-teks Al Quran yang berbicara tentang Israel untuk menganalisis kedua perspektif itu. Kesimpulan yang didapatkan adalah bahwa perspektif pertama dipengaruhi oleh ayat-ayat Al Quran yang menggambarkan orang-orang Yahudi sebagai kelompok dengan berbagai sifat buruk. Sebaliknya, perspektif kedua menggunakan ayat-ayat yang menggambarkan citra positif kaum Yahudi sebagai dasar pemikiran.

Kata Kunci: Al Quran, Islam, konflik Israel-Palestina, Yahudi.

\section{Pendahuluan}

Pasca Perang Dunia Kedua, kawasan Timur Tengah hingga kini menjadi salah satu titik pergolakan paling panas di dunia. Konflik Palestina dan Israel bisa disebut sebagai pusat dari segala kekisruhan di Timur Tengah. Israel, Palestina, Islam, Arab, dan Yahudi menjadi kata-kata yang paling sering disebut ketika orang-orang membicarakan Timur Tengah dan politik internasional yang melibatkan berbagai kekuatan adidaya, termasuk AS, Perancis, Inggris, dan Jerman. Dapat dikatakan bahwa Islam menjadi salah satu kata kunci yang sangat penting; pergolakan dunia tidak mungkin dibahas tanpa membicarakan konflik Israel-Palestina, dan konflik keduanya tidak mungkin dibahas tanpa melibatkan agama Islam.

Ada dua perspektif utama di kalangan internal umat Islam dalam melihat peta konflik Israel-Palestina. Perspektif pertama memandang bahwa apa yang terjadi di Palestina adalah konflik antaragama: Yahudi melawan Islam. Dalam pandangan kelompok pertama ini, Islam dan Yahudi adalah dua agama yang satu sama lain memiliki misi untuk saling menaklukkan. ${ }^{1}$

Adapun perspektif kedua menyatakan bahwa akar masalah Palestina bukanlah konflik agama, melainkan sesuatu yang lain, yaitu kemanusiaan, keadilan, dan perlawanan terhadap imperialisme. Akan tetapi, keyakinan inipun ujung-ujungnya menyentuh masalah-masalah agama. Sebabnya adalah, pertama, semua aliran dalam

1 Salah satu teks agama yang sering dijadikan sebagai argumen oleh kelompok ini adalah Al Quran surah Al Baqarah ayat 120 yang berbunyi: “Orang-orang Yahudi dan Nasrani tidak akan senang kepada kalian hingga kalian mengikuti agama mereka." Ayat ini, berdasarkan pendapat kelompok pertama tersebut, menginformasikan adanya tekad dari kaum Yahudi (dan Nasrani) untuk menaklukkan kaum Muslimin. Sebagai reaksi atas keinginan mereka itu, umat Islam harus melawan dan juga melakukan hal yang sama, yaitu penaklukkan atas orang-orang Yahudi (dan Nasrani). 
Islam sepakat bahwa perlawanan terhadap kezaliman dan penegakan keadilan termasuk salah satu ajaran penting agama Islam. ${ }^{2}$ Kedua, dalam konflik Palestina, yang menjadi korban adalah saudara-saudara seiman bagi kaum Muslimin. Sejumlah teks agama mengajarkan prioritas utama pembelaan terhadap saudara seiman yang menjadi korban ketidakadilan. ${ }^{3}$

Jadi, meskipun berbeda dalam memandang akar masalah, kedua perspektif di kalangan internal umat Islam itu tetap menempatkan agama sebagai faktor yang sangat penting. Dalam artikel ini, penulis akan memaparkan sejumlah ayat-ayat Al Quran yang terkait dengan sejarah Israel dan sikap buruk Bani Israel sepanjang sejarah; ayat-ayat inilah yang sering menjadi landasan bagi kelompok yang meyakini perspektif pertama. Selanjutnya, penulis akan memaparkan sejumlah ayat-ayat Al Quran yang justru memuji kaum Yahudi dalam kondisi-kondisi tertentu; dan hal ini yang menjadi pemikiran bagi kelompok kedua yang meyakini bahwa konflik IsraelPalestina bukanlah konflik antaragama.

\section{Al Quran Sebagai Sumber Sejarah}

AI Quran adalah teks agama paling penting bagi umat Islam. Ini adalah kitab suci yang diyakini oleh umat Islam sebagai sumber petunjuk bagi kehidupan mereka. Kitab ini berisikan sejumlah hal, yaitu akidah, syariah (ibadah dan muamalah), akhlak, kisah-kisah lampau (sejarah), berita-berita yang akan datang dan pengetahuanpengetahuan Ilahi penting lainnya (Anshari, 1983: 43). Dengan demikian, sejarah adalah salah satu isi penting kitab ini. Hanafi menyatakan bahwa dari keseluruhan surah Al Quran, ada 35 surah yang memuat kisah sejarah, jumlah ayatnya lebih kurang 1.600 ayat dari keseluruhan ayat AI Quran yang berjumlah 6.342 ayat (Hanafi, 1984: 22).

Cara Al Quran membuat deskripsi sejarah umat manusia, menurut Al-Qathan, bersifat shurah natiqah, yang bermakna seolah-olah pembaca kisah tersebut menjadi pelaku sendiri yang menyaksikan peristiwa itu. Menurutnya pula, kisah-kisah dalam Al-Qur'an dikelompokkan menjadi tiga: (1) kisah para nabi terdahulu, (2) kisah-kisah

2 Di antara ayat-ayat Al Quran yang berbicara tentang kewajiban kaum Muslimin untuk menegakkan keadilan adalah An Nisa ayat 135 dan Al Hadid ayat 25 berikut ini.

"Wahai orang-orang yang beriman, jadilah kalian orang-orang yang benar-benar menegakkan keadilan, menjadi saksi/teladan karena Allah (dalam urusan keadilan ini), meskipun (keadilan itu harus kalian tegakkan) atas diri kalian sendiri, atau terhadap orang tua, serta kaum kerabat kalian." (An Nisa: 135) "Sesungguhnya Kami telah mengutus rasul-rasul Kami dengan membawa bukti-bukti yang nyata dan telah Kami turunkan bersama mereka AI Kitab dan neraca supaya manusia dapat melaksanakan keadilan." (Al Hadid: 25)

3 Dalam sebuah hadis yang terkenal, Nabi Muhammad menyatakan bahwa jika seorang Muslim tidak memikirkan nasib yang menimpa saudara seimannya, ia tidak dihitung sebagai pengikut Nabi. (Naisaburi, 2001, hadis nomor 7.889) 
tentang umat dan tokoh terdahulu yang tidak dapat dipastikan kenabiannya seperti kisah Talut, Jalut, Ashabul Kahfi, Zulkarnain, dan sebagainya, serta (3) kisah-kisah yang berkaitan dengan peristiwa-peristiwa yang terjadi di zaman Rasulullah SAW, seperti peristiwa hijrah, Perang Badar, Perang Uhud, dan lain-lain. (Qattan, 1992: 15).

Para ilmuwan mendefinisikan sejarah sebagai deskripsi peristiwa penting yang terjadi di masa lampau. Menurut Kartodirdjo, dalam sejarah ada upaya untuk merekonstruksikan "peristiwa penting yang terjadi" di masa lampau dan hasil dari rekonstruksi itu diuraikan sebagai cerita. Dengan kata lain, kejadian-kejadian penting itu diseleksi dan diatur menurut proses waktu sedemikian sehingga tersusun sebagai cerita (Kartono, 1984: 5).

Seleksi dan rekonstruksi juga menjadi titik perhatian sejarawan Taufik Abdullah. Menurutnya, peristiwa masa lalu yang dapat dimasukkan ke dalam konteks historis adalah peristiwa "yang penting" dan "berkaitan" dengan proses sejarah yang sudah diseleksi. Abdullah (1982: 414) juga menegaskan bahwa peristiwa sejarah adalah peristiwa yang secara riil ataupun dalam anggapan terkait satu sama lain, hingga ia menjadi bagian dari suatu proses yang menentukan arah perkembangan masyarakat. Proses seleksi dan rekonstruksi sebagaimana yang ditegaskan oleh para sejarawan di atas terkait erat dengan masalah sumber sejarah.

Apa saja yang bisa dijadikan sebagai sumber sejarah? Sebagaimana yang dikutip oleh Majid (2013:3), Gottschalk menyatakan bahwa sesuatu bisa disebut sebagai sumber sejarah yang asli bila mencakup lima ketentuan: (1) karena mengandung gagasan yang segar dan kreatif, (2) karena tidak diterjemahkan dari bahasa yang dipergunakan untuk menuliskannya, (3) karena berada dalam tahapan yang paling awal dan belum mengalami rekayasa (4) karena teksnya yang merupakan teks yang disepakati oleh masyarakat penggunanya sebagai teks yang belum mengalami perubahan dan pergantian, dan (5) karena merupakan sumber yang paling awal yang didapat mengenai informasi yang dikandungnya. Majid (2013) juga menyatakan bahwa fakta-fakta sebagai sumber sejarah terbagi menjadi tiga: (1) sumber lisan, (2) sumber tulisan; dan (3). visual.

Terkait dengan sifat sumber sejarah, Majid membagi sumber tersebut menjadi dua kategori: sumber primer dan sumber sekunder. Sumber primer merupakan kesaksian dari seseorang saksi atau lebih dengan mata kepala sendiri atau dengan panca indera atau dengan alat bantu. Model kesaksian ini biasa disebut dengan saksi pandangan mata. Sementara sumber sekunder merupakan kesaksian dari seseorang yang tidak hadir pada peristiwa yang dikisahkan. 
Dari berbagai definisi dan penjelasan di atas, dapat disimpulkan bahwa sebagai kitab suci, Al Quran bisa dikategorikan sebagai sumber sejarah yang asli/otentik serta berbentuk tulisan. Adapun terkait dengan sifat sumbernya, sebagian ayat Al Quran yang bercerita tentang sejarah umat dan para nabi/tokoh sejarah di masa sebelum Nabi Muhammad dikategorikan sebagai sumber sekunder, meskipun cara Al Quran menuturkannya seolah-olah ada saksi sejarah yang menyaksikannya secara langsung. Sementara itu, terkait dengan ayat-ayat Al Quran yang diturunkan seiring dengan peristiwa yang terjadi di masa Nabi Muhammad dikategorikan sebagai sumber primer.

Baik bersifat primer ataupun sekunder, AI Quran dikategorikan sebagai salah satu sumber sejarah yang sangat penting, terutama karena kitab yang berisikan catatan sejarah ini secara empiris terbukti tetap otentik sejak masa dikodifikasikannya hingga zaman sekarang.

\section{Citra Baik Bani Israil dalam Al Quran}

Di dalam Al Quran, ada banyak ayat yang berbicara tentang kaum Bani Israil atau Yahudi dengan pujian sehingga memunculkan citra positif atau baik. Antara lain, Al Quran menyebut Bani Israil sebagai kaum terpilih, sebagaimana ayat berikut.

"Hai Bani Israil, ingatlah akan nikmat-Ku yang telah Aku anugerahkan kepada kalian dan (ingatlah pula) bahwasanya Aku telah melebihkan kalian atas segala umat. (Al Baqarah: 47)

Keistimewaan Bani Israil tersebut tidak lepas dari masa lalu mereka yang berdasarkan kepada catatan sejarah Al Quran, selalu terhubung dengan banyak nabi-nabi besar. Berikut ini adalah para nabi yang ada hubungannya dengan Bani Israil.

\section{Nabi Ibrahim}

Seluruh agama besar dunia (Islam, Kristen, dan Yahudi) sepakat bahwa bangsa Israel (Bani Israil) serta kaum Yahudi adalah keturunan Nabi Ibrahim (Abraham). Di dalam Al Quran, Nabi Ibrahim adalah utusan Allah yang tergolong dalam kelompok Ulul 'Azmi, yaitu para nabi yang memiliki keistimewaan dari sisi ketangguhan mereka dalam menempuh berbagai kesulitan hidup yang amat berat. Menurut Al Quran, Allah SWT telah memilih anak-anak dan keturunan Ibrahim sebagai nabi yang

4 Selain ayat ini, penegasan bahwa Israil adalah umat terpilih juga dicantumkan dalam surah yang sama, yaitu pada ayat 40 dan ayat 107. 
diutus ke tengah berbagai bangsa di seluruh penjuru dunia. Kemuliaan Ibrahim juga ditandai dengan posisinya sebagai datuk bagi nabi umat Islam, yaitu Muhammad SAW.

Berikut ini adalah beberapa ayat Al Quran yang menyebut nama Ibrahim, serta konteks penyebutan namanya itu.

- Al Quran memuji Ibrahim dan menyebutnya sebagai umat, walaupun ia sebenarnya hanya satu orang.

"Sesungguhnya Ibrahim adalah satu 'umat' yang patuh dan cenderung kepada Allah. Dan sekali-kali, dia bukanlah termasuk orang-orang yang mempersekutukan (Tuhan)". (Al Nahl: 120)

- Ibrahim disebut sebagai contoh terbaik bagi para pejuang kebenaran sepanjang sejarah.

"Sesungguhnya telah ada suri teladan yang baik bagimu pada Ibrahim dan orang-orang yang bersama dengan dia; ketika mereka berkata kepada kaum mereka: 'Sesungguhnya kami berlepas diri dari kalian dan dari apa yang kalian sembah selain Allah. Kami ingkari kekafiran kalian. Telah nyata antara kami dan kalian permusuhan dan kebencian buat selama-lamanya sampai kalian beriman kepada Allah saja." (Al Mumtahanah: 4)

- $\quad$ Allah menyebut lbrahim sebagai al-khalil (sahabat yang disayang).

"Dan Allah mengambil Ibrahim menjadi kesayangan-Nya (kekasih-Nya)". (Al Nisa: 125$)$

- Ibrahim mendapatkan keturunan anak yang saleh, setelah sebelumnya, ia banyak berdoa.

"Ya Tuhanku, anugerahkanlah kepadaku (seorang anak) yang termasuk orang-orang yang saleh. Maka Kami beri dia kabar gembira dengan seorang anak yang amat sabar." (Al Shafat: 100-101)

“Dan Kami beri dia kabar gembira dengan kelahiran Ishaq, seorang nabi yang saleh." (Al Shafat: 112)

- Dari anak keturunan Ibrahim akan lahir para imam bagi umat manusia.

“Dan ketika Ibrahim diuji Tuhannya dengan beberapa kalimat (ujian), lalu ia menunaikannya. Allah berfirman: 'Sesungguhnya Aku akan menjadikanmu imam bagi seluruh manusia.' Ibrahim berkata:'(Aku memohon) dari keturunanku 
juga.' Allah berfirman: 'Janji-Ku tidak mengenai orang yang zalim." (Al Baqarah: 124)

\section{Nabi Ismail}

Ismail adalah putera Nabi Ibrahim, sebagaimana disebutkan dalam ayat berikut ini.

Segala puji bagi Allah yang telah menganugerahkan kepadaku di hari tua Ismail dan Ishaq. Sesungguhnya Tuhanku, benar-benar Maha Mendengar do'a. (Ibrahim: 36)

Dalam Ensiklopedia Sejarah Islam yang ditulis Tu'aimah, disebutkan bahwa Ismail adalah anak pertama dari Ibrahim, dan catatan sejarah ini berbeda dengan apa yang dituliskan oleh para sejarawan Yahudi yang menyatakan bahwa Ismail adalah anak kedua, adapun anak pertama Ibrahim adalah Ishaq (Kashfi, 2016: 26).

Ismail mempunyai 10 atau 12 orang anak. Salah seorang darinya bernama Qaidar, yang kemudian menjadi datuk dari Nabi Muhammad. Catatan sejarah menunjukkan bahwa umur Ismail mencapai 137 tahun dan ia meninggal dunia di Mekah, lalu dikebumikan di sisi Kabah yang kini dikenal dengan nama Hijr Ismail (Kashfi, 2016: 29).

Sebagai putera Nabi Ibrahim dan kakak dari Nabi Ishaq (kelak Ishaq melahirkan Ya'qub), Ismail adalah paman dari Nabi Ya'qub. Sementara itu, Ya'qub dijuluki Israil dan menjadi bapak bagi Bani Israil. Jadi, Ismail memiliki kaitan erat dengan anakanak Israil.

\section{Nabi Ishaq}

Al Quran menceritakan bahwa Ishaq adalah anak kedua Nabi Ibrahim dan Al Quran menyifatinya sebagai anak lelaki yang berilmu. Adapun bagi Ismail, Al Quran menyebutnya sebagai anak yang penyabar. Kabar gembira tentang kelahiran Ishaq datang beberapa tahun setelah kelahiran Ismail

"Dan istrinya (Sarah) berdiri (di balik tirai) lalu dia tersenyum. Maka Kami sampaikan kepadanya berita gembira tentang (kelahiran) Ishaq dan dari Ishaq (akan lahir putranya) Ya'qub." (Hud: 71)

Al Quran menyatakan bahwa sebagai penerus ayahandanya, Ishaq juga mengikuti agama Ibrahim. 
Nama Ishaq disebut 10 kali oleh Al Quran di tempat yang berlainan. Dia diperkenalkan sebagai seorang yang menjadi panutan, berkedudukan tinggi, serta tergolong dari kalangan nabi dan orang yang baik.

“Katakanlah: 'Kami beriman kepada Allah dan kepada apa yang diturunkan kepada kami dan yang diturunkan kepada Ibrahim, Ismail, Ishaq, Ya'qub, dan anak-anaknya, dan apa yang diberikan kepada Musa, Isa dan para nabi dari Tuhan mereka. Kami tidak membeda-bedakan seorang pun di antara mereka dan hanya kepada-Nya-lah kami menyerahkan diri." (Ali Imran: 84)

\section{Nabi Ya'qub dan Bani Israil}

Ya'qub adalah putera dari Ishaq, dan dialah yang memiliki gelar Israil yang bermakna 'hamba Tuhan'. Dari gelar yang dimiliki Ya'qub inilah muncul istilah Bani Israil yang bermakna anak keturunan Israil. Jadi, mereka yang kini dikenal sebagai Israel adalah anak keturunan Nabi Ya'qub.

Ya'qub memainkan peranan yang sangat penting untuk meneruskan kenabian dari trah Ibrahim. la juga berperan sebagai sosok yang membuat Bani Israil sebagai satu bangsa yang terpisah, terutama ketika anaknya yang bernama Yusuf memegang amanah harta kerajaan Mesir dan mempunyai dua tugas, yaitu sebagai nabi dan penguasa.

Al Quran juga menerangkan keadaan Ya'qub dan menggambarkannya sebagai salah satu nabi utusan Allah SWT yang mempunyai sifat sabar yang tinggi ketika berpisah dengan anaknya, Yusuf.

Seterusnya, setiap anak Ya'qub menjadi sumber keberadaan beberapa suku Bani Israil. Sejarah mencatat bahwa mereka menjadi tokoh-tokoh terkemuka serta memainkan banyak sekali peranan penting. Al Quran menceritakan titik permulaan sejarah mereka sebagai berikut.

"Dan mereka Kami bagi menjadi dua belas suku yang masing-masingnya berjumlah besar..." (Al A'raf: 160)

Juga firman Allah yang lain:

“Dan Kami bagi-bagi mereka di dunia ini menjadi beberapa golongan; di antaranya ada orang-orang yang saleh dan di antaranya ada yang tidak demikian. Dan Kami coba mereka dengan (nikmat) yang baik-baik dan (bencana) yang buruk-buruk, agar mereka kembali (kepada kebenaran)." (Al A'raf: 168) 


\section{Nabi Yusuf}

Nabi Ya'qub mempunyai dua belas orang anak. Salah seorang di antaranya adalah Yusuf yang dipilih oleh Allah SWT sebagai nabi. Pada diri Yusuf terkumpul kekuasaan dalam bentuk kerajaan serta kenabian. Dia merupakan titik permulaan dalam sejarah keturunan Ibrahim yang memperlihatkan bahwa kerajaan dapat bergabung dengan kenabian, sebagaimana yang kemudian ditunjukkan oleh Daud dan Sulaiman.

NabiYusuf dalam hidupnya menunaikan kewajiban mengurus dan menjaga anakanak dari saudaranya. Kemudian, ketika ia hampir meninggal dunia, ia memberi tahu mereka apa yang akan mereka jalani, yaitu berupa musibah dan kepahitan hidup yang parah. Mereka juga diberitahu tentang berita gembira, yaitu tentang kelahiran seorang nabi yang bernama Musa bin Imran dan ia akan datang menyelamatkan Bani Israil dari kekejaman Firaun.

Al Quran menceritakan kisah Yusuf dalam beberapa surah. Bahkan, Yusuf menjadi salah satu nama surah dalam Al Quran. Kitab suci ini mengisahkan Yusuf dengan menitikberatkan kepada beberapa karakternya yang mulia, seperti sifat amanah dan keteguhannya dalam menjauhi segala maksiat. Dalam surah ini terdapat berbagai pelajaran dan panduan yang dapat diambil dan dijadikan contoh bagi generasi mendatang.

"Sesungguhnya ada beberapa tanda-tanda kekuasaan Allah pada (kisah) Yusuf dan saudara-saudaranya bagi orang-orang yang bertanya." (Yusuf: 7)

Tetapi, dalam catatan sejarah Al Quran, pada masa Yusuf ini pula muncul benih-benih keburukan pada Bani Israil. Dimulai sejak munculnya kedengkian dari saudara-saudara Yusuf kepadanya, hingga ada upaya pembunuhan terhadap Yusuf. Ketika akhirnya saudara-saudara Yusuf mengakui kesalahan mereka, dan Yusuf pun memaafkannya, Allah pun menerima taubat mereka.

\section{Nabi Musa}

Agama Islam meyakini bahwa Musa adalah salah seorang nabi terkemuka dan tergolong dari kalangan nabi yang disebut Ulul Azmi (pemilik cita-cita agung). Menurut Islam, tugas utama Nabi Musa adalah berjuang menentang kezaliman sekaligus menyelamatkan Bani Israil dari cengkaman kekuasaan Firaun yang kejam.

“Musa berkata kepada kaumnya: 'Mohonlah pertolongan kepada Allah dan bersabarlah; sesungguhnya bumi (ini) kepunyaan Allah; dipusakakan-Nya 
kepada siapa yang dikehendaki-Nya dari hamba-hamba-Nya. Dan kesudahan yang baik diperuntukkan bagi orang-orang yang bertakwa".

Kaum Musa berkata:'Kami telah ditindas (oleh Firaun) sebelum dan sesudah kamu datang kepada kami'. Musa menjawab: 'Mudah-mudahan Allah membinasakan musuh kalian dan menjadikan kalian khalifah di bumi (Nya), maka Allah akan melihat bagaimana perbuatan kalian." (Al A'raf: 128-129)

Setelah mendapat perintah Allah, barulah Musa dan pengikutnya keluar pada waktu malam. Ketika hal itu diketahui oleh Firaun dan pasukannya, mereka pun mengejar Musa dari belakang hingga sampai ke pantai laut. Lewat perintah Allah, Musa memukul air laut dengan tongkatnya. Lalu, dia dan pengikutnya menyeberangi laut dengan selamat.

Firaun dan pasukannya mengejar Nabi Musa a.s. dari belakang. Tetapi mereka tenggelam di dalam laut, setelah laut yang terbelah itu menyatu kembali. Dengan demikian, kerajaan Mesir jatuh ke tangan Bani Israil.

"Maka Kami keluarkan Firaun dan kaumnya dari taman-taman dan mata air, dan (dari) perbendaharaan dan kedudukan yang mulia. Demikianlah Kami anugerahkan semuanya (itu) kepada Bani Israil. " (Al Syuara: 57-59)

Setelah Musa menyeberangi lautan itu dan sampai ke tempat yang tenang dan aman, tugasnya pun beralih pada aspek lain, yaitu memimpin masyarakat untuk bergerak maju dan menyusun sebuah pemerintahan yang bercorak keagamaan. Akan tetapi, upaya Musa ini mendapatkan tantangan yang luar biasa besar dari Bani Israil sendiri. Ketika mereka bertemu dengan suatu kaum yang menyembah patung berhala, mereka pun teringat pada masa lalu di Mesir ketika mereka selalu menyembah berhala. Lalu mereka pun meminta kepada Musa supaya dibuatkan sebuah patung berhala untuk disembah.

Lalu, sampailah masa ketika Allah menyuruh Musa untuk pergi ke Bukit Tursina (Sinai) untuk menerima beberapa ayat dan mempersiapkan dirinya untuk menerima Taurat. Inilah kitab yang kemudian menjadi kitab suci kaum Yahudi.

Maka Musa pun menitipkan Bani Israil kepada saudaranya, Harun. Lalu ia pergi ke Bukit Tursina selama 40 hari. Namun, pada masa itulah seorang yang bernama Samiri dengan bantuan sekelompok umat Musa menentang Harun. Samiri membuat sebuah patung berupa anak lembu untuk disembah. Walaupun Harun berusaha 
sekuat tenaga menghalangi dan menasihati mereka, usahanya tetap gagal. Keadaan ini berlangsung hingga Musa kembali pulang.

Saat pulang, Musa bercerita kepada kaumnya tentang keagungan Tuhan dan keindahan surga. Musa juga menunjukkan kitab Taurat yang ada di tangannya.

"Dan telah Kami tuliskan untuk Musa pada lauh-lauh (lempengan-lempengan Taurat) segala sesuatu sebagai pelajaran dan penjelasan bagi segala sesuatu; maka (Kami berfirman): 'Berpeganglah kepadanya dengan teguh dan suruhlah kaummu berpegang kepada (perintah-perintahnya) dengan sebaik-baiknya, nanti Aku akan memperlihatkan kepadamu negeri orang-orang yang fasik." (Al A'raf: 145)

Tetapi kemudian ketika Musa melihat umatnya telah memilih maksiat dan dosa selama ketidakhadirannya. la pun bertanya kepada saudaranya Harun dengan penuh kecewa dan amarah sehingga tubuhnya menggigil. Lalu jatuhlah Taurat dari tangannya.

"Dan tatkala Musa telah kembali kepada kaumnya dengan marah dan sedih hati berkatalah dia: 'Alangkah buruknya perbuatan yang kamu kerjakan sesudah kepergianku! Apakah kamu hendak mendahului janji Tuhanmu?" Dan Musa pun melemparkan lauh-lauh (lempengan-lempengan Taurat) itu dan memegang (rambut) kepala saudaranya (Harun) sambil menariknya ke arahnya..."(Al A'raf: 150)

Dalam sebuah hadis, dikatakan bahwa ketika lauh tersebut terlepas dari tangan Musa dan jatuh ke tanah, maka bumi menelan sebagian lauh tersebut, dan sebagian yang lain pecah dan sisanya utuh baik. Dikatakan bahwa itu adalah pertanda umatnya akan melanggar perintah-perintahnya (Kashfi, 2016: 38). Lempengan-lempengan Taurat itu jatuh ke tanah hingga sebagiannya pecah. Ibarat cahaya matahari yang baru bersinar lalu tertelan gerhana sebagian, lempengan Taurat yang baru saja dibawa Musa itu pun sudah tidak lagi utuh.

Bani Israil terus menentang dan menolak sisa kandungan Taurat. Mereka menentang Musa dengan begitu hebat sehingga Allah SWT mengancam mereka dengan meletakkan gunung di atas mereka supaya mereka patuh. Kalau tidak, gunung itu akan jatuh menimpa mereka.

"Dan (ingatlah) ketika Kami mengangkat bukit ke atas mereka seakan-akan bukit itu naungan awan dan mereka yakin bahwa bukit itu akan jatuh menimpa mereka. (Dan Kami katakan kepada mereka): 'Peganglah dengan teguh apa 
yang telah Kami berikan kepadamu, serta ingatlah selalu (amalkanlah) apa yang tersebut di dalamnya supaya kamu menjadi orang-orang yang bertakwa." (Al A'raf: 171)

Kisah Nabi Musa berikut lika-liku interaksinya dengan Bani Israil menjadi kisah terbesar dan terpanjang dalam Al Quran. Bahkan, surah terpanjang dalam Al Quran bernama Al Baqarah yang bermakna sapi betina. Nama ini merujuk kepada kisah Nabi Musa yang menjadikan ekor sapi betina sebagai mukjizat keajaiban dalam mengungkap misteri pembunuhan yang terjadi di kalangan Bani Israil.

Secara keseluruhan, dalam surah AI Baqarah itu dan juga di surah-surah lainnya, Bani Israil mendapatkan kritikan dan kecaman yang sangat tajam akibat banyaknya pembangkangan dan perbuatan jahat yang mereka tunjukkan kepada Nabi Musa, dan juga kepada para nabi lainnya.

\section{Nabi Harun}

Harun adalah saudara kandung Musa. Oleh karena lidah dan penuturannya lebih fasih dibanding Musa maka Musa pun meminta kepada Allah SWT supaya Harun menemaninya dalam menyampaikan risalahnya, yaitu sebagai wazir (menteri) dan pembantunya, lalu Allah memperkenankan permintaannya.

“Dan jadikanlah untukku seorang pembantu dari keluargaku, (yaitu) Harun, saudaraku. Teguhkanlah dengan dia kekuatanku, dan jadikanlah dia sekutu dalam urusanku, supaya kami banyak bertasbih kepada Engkau, dan banyak mengingat Engkau. Sesungguhnya Engkau adalah Maha Melihat (keadaan kami)." (Thaha: 29-35)

Harun dan Musa dipertautkan dengan dua hubungan: hubungan wazir atau pembantu dan juga hubungan saudara kandung. Oleh karena itu, Musa menunjuknya sebagai pengganti ketika Musa pergi ke Bukit Tursina.

"Dan telah Kami janjikan kepada Musa (untuk memberikan Taurat) sesudah berlalu waktu tiga puluh malam, dan Kami sempurnakan jumlah malam itu dengan sepuluh (malam lagi). Maka sempurnalah waktu yang telah ditentukan Tuhannya selama empat puluh malam. Dan berkata Musa kepada saudaranya yaitu Harun: 'Gantikanlah aku dalam (memimpin) kaumku, dan perbaikilah, dan janganlah kamu mengikuti jalan orang-orang yang membuat kerusakan." (Al A'raf: 42) 
Penjelasan Al Quran menunjukkan bahwa seperti Musa, Harun juga adalah nabi dan rasul yang diutus Allah. Karena ia juga seorang nabi, kedudukannya juga setaraf dengan para nabi yang lain dan mempunyai sifat-sifat yang sama seperti mereka.

\section{Nabi Daud}

Daud adalah seorang tokoh yang juga sangat dimuliakan oleh Bani Israil. Kisah Daud yang bertubuh kecil tetapi mampu mengalahkan raksasa Jalut (Goliat) menjadi kisah epik yang utama dalam tradisi Bani Israil. AI Quran juga menempatkan Daud sebagai salah seorang nabi yang sangat mulia. Menurut Al Quran, Allah mengaruniakan kepada Daud bakat dan ilmu serta menjadikannya seorang yang mulia dan berkuasa hingga layak menjadi seorang nabi dan raja sekaligus.

Kisah epik Daud melawan Jalut juga disebutkan oleh Al Quran:

"Mereka (tentara Thalut) mengalahkan tentara Jalut dengan izin Allah dan (dalam peperangan itu) Daud membunuh Jalut, kemudian Allah memberikan kepadanya (Dawud) pemerintahan dan hikmah, (sesudah meninggalnya Thalut) dan mengajarkan kepadanya apa yang dikehendaki-Nya. Seandainya Allah tidak menolak (keganasan) sebahagian manusia dengan sebahagian yang lain, pasti rusaklah bumi ini. Tetapi Allah mempunyai karunia (yang dicurahkan) atas semesta alam." (Al Baqarah: 251)

Nabi Daud menerima sebuah kitab yang diturunkan dari langit, yaitu kitab Zabur. Kitab ini mempunyai nilai istimewa baik dari segi waktunya, kandungannya, dan kalimat-kalimatnya, sehingga kitab itu dianggap sebagai sumber ilmu yang paling kaya di dalam khazanah ilmu Islam.

"Sesungguhnya Kami telah memberikan wahyu kepadamu sebagaimana Kami telah memberikan wahyu kepada Nuh dan nabi-nabi yang kemudiannya, dan Kami telah memberikan wahyu kepada Ibrahim, Isma'il, Ishaq, Ya'qub dan anak cucunya, 'Isa, Ayyub, Yunus, Harun dan Sulaiman. Dan Kami berikan Zabur kepada Daud." (Al Nisa: 163)

Nabi Daud juga disebut oleh Al Quran sebagai seorang nabi yang memiliki peranan sentral dalam membangun peradaban Bani Israil. Allah memberikan kepada Daud pengetahuan kebijakan dan kerajaan.

"Dan Kami kuatkan kerajaannya dan Kami berikan kepadanya hikmah dan kebijaksanaan dalam menyelesaikan perselisihan."(Shad: 20) 


\section{Nabi Sulaiman}

Sulaiman adalah anak bungsu Nabi Daud. Al Quran menyatakan bahwa Sulaiman adalah ahli waris bagi posisi kenabian dan kerajaan Nabi Daud.

“Dan Sulaiman telah mewarisi Daud, dan dia berkata: 'Hai Manusia, kami telah diberi pengertian tentang suara burung dan kami diberi segala sesuatu. Sesungguhnya ini benar-benar suatu kurnia yang nyata". (AI Naml: 16)

Cerita sangat terkenal terkait Nabi Sulaiman di dalam Al Quran adalah kisahnya saat mendakwahi Balqis, Ratu Kerajaan Saba, yang tinggal di selatan Jazirah Arab. Sulaiman berhasil menaklukkan Saba dengan hanya menghantar sepucuk surat dan membawa singgasana Balqis secara ajaib, yaitu dengan perantaraan washi-nya yang bernama Ashif bin Barkhia. Singgasana itu dipindahkan dari Saba ke Palestina hanya dalam sekejap mata.

AI Quran menggambarkan Sulaiman dan ayahnya, Daud, dengan penggambaran sosok-sosok manusia suci yang bermartabat dan mulia. Akan tetapi, sebagaimana yang dikutip oleh Kashfi (2016: 38), di dalam kitab suci kaum Yahudi, Nabi Daud dan anaknya digambarkan sebagai dua manusia yang mempunyai nafsu seks yang luar biasa sehingga melampaui batas hak orang lain. Disebutkan dalam kitab suci itu bahwa kenabian mereka telah dicabut dan yang tinggal hanya kedudukan mereka sebagai raja atau pemerintah saja.

Kaum Yahudi pada zaman sekarang mempercayai cerita seperti yang disebutkan di atas. Akan tetapi, terjadi perbedaan pendapat mengenai apakah perilaku buruk itu sampai mencabut dan mengangkat kedudukan kenabian mereka. Yang pasti, para pemuka agama Yahudi yang menulis kitab Taurat sepertinya memandang kedua nabi itu pada satu aspek saja, yaitu aspek keduniaan dan pemerintahan lalu menggambarkan keduanya dengan gambaran yang sangat tidak layak untuk dituliskan. ${ }^{5}$

Kemudian kerajaan Nabi Sulaiman terbagi menjadi dua bagian, yaitu Israil dan Yahuda. Sebuah buku berjudul "Pertentangan Dalam Sejarah dan Peristiwa dalam Taurat" menyatakan, kerajaan Nabi Sulaiman berpecah menjadi dua. Keduanya terbagi pula pada pemerintahan-pemerintahan kecil, jumlahnya sampai 20 pemerintahan kecil yang saling berkonflik (Kashfi, 2016: 40).

Sejak zaman Sulaiman hingga kebangkitan Isa, banyak para nabi dan rasul diutus dari kalangan Bani Israil.

$5 \quad$ Kashfi mengutip keterangan yang terdapat pada kitab hadis Al Bihar jilid XIII halaman 169. 
“Dan sesungguhnya Kami telah mendatangkan Al Kitab (Taurat) kepada Musa, dan Kami telah menyusulinya (berturut-turut) sesudah itu dengan rasul-rasul, dan telah Kami berikan bukti-bukti kebenaran (mukjizat) kepada Isa putra Maryam dan Kami memperkuatnya dengan Ruhulkudus. (Al Baqarah: 87)

\section{Isa Al Masih}

Isa Al Masih adalah salah satu sosok sentral sekaligus kontroversial dalam kepercayaan tiga agama besar dunia. Bagi umat Kristen, Isa atau Yesus adalah anak Tuhan. Sedangkan kaum Yahudi (Israil) malah menolak Isa. Catatan sejarah menunjukkan bahwa kaum Yahudi bersama-sama dengan pemerintah Romawi adalah pelaku penyaliban (dalam kepercayaan Islam, yang disalib bukanlah Isa, melainkan orang yang diserupakan dengan Isa AI Masih). Adapun dalam Islam, Isa AI Masih adalah salah satu nabi yang diutus untuk Bani Israil.

Al Quran menyebut Al Masih sebagai "kalimat Allah" yang ditempatkan dalam diri wanita suci Sayidah Maryam. Allah menjadikan dia dan ibunya sebagai salah satu tanda kekuasaan-Nya di seluruh alam.

"Sesungguhnya Al Masih, 'Isa putera Maryam itu, adalah utusan Allah dan kalimat-Nya yang disampaikan-Nya kepada Maryam, dan ruh dari-Nya." (AI Nisa:

Al Quran juga menggambarkan Isa Al Masih sebagai sosok yang zuhud, atau menjauhi kemewahandalam kehidupannya di dunia, walaupun ia hidup di tengahtengah manusia yang gemar mengumpulkan harta dan kekayaan. la tetap duduk bersila di atas bumi tanpa tikar, beratapkan langit dan memakan makanan yang paling mudah ditemui sehingga ia hanya makan dedaunan pohon saja. la meninggalkan segala kelezatan duniawi dan 'mencampakkan' segala kelezatan itu ke dinding supaya ia diikuti oleh para pengikutnya. Dengan demikian, mereka dapat keluar dari belenggu hawa nafsu dan memiliki sifat sebagai manusia yang sebenarnya (Kashf, 2016: 43).

Dalam catatan Al Quran, Kaum Yahudi disebut-sebut sangat membenci Isa AI Masih. Puncak dari kebencian itu ditunjukkan dengan upaya untuk menyalibnya. Lalu, Allah menjadikan rupa Isa pada seorang Yahudi yang mengkhianati Isa dan ia pun ditangkap lalu disalib sehingga mati. ${ }^{6}$

\footnotetext{
6 Inilah sebabnya orang Kristen menjadikan salib sebagai hiasan dan lambang mereka.
} 
“Dan karena ucapan mereka: 'Sesungguhnya Kami telah membunuh Al Masih, Isa putra Maryam, Rasul Allah'. Padahal mereka tidak membunuhnya dan tidak (pula) menyalibnya, tetapi (yang mereka bunuh ialah) orang yang diserupakan dengan Isa bagi mereka. Sesungguhnya orang-orang yang berselisih paham tentang (pembunuhan) Isa, benar-benar dalam keragu-raguan tentang yang dibunuh itu. Mereka tidak mempunyai keyakinan tentang siapa yang dibunuh itu, kecuali mengikuti persangkaan belaka. Mereka tidak (pula) yakin bahwa yang mereka bunuh itu adalah Isa. Tetapi (yang sebenarnya), Allah telah mengangkat Isa kepada-Nya. Dan adalah Allah Maha Perkasa lagi Maha Bijaksana... (Al Nisa: 157)

Terkait dengan kisah Nabi Isa ini, Al Quran menyatakan bahwa sikap kedua agama besar (Yahudi dan Kristen) terhadap Isa Al Masih adalah sikap yang ekstrem. Yahudi dianggap bersikap ekstrem karena menolak mentah-mentah Isa AI Masih, bahkan berniat membunuhnya. Adapun Kristen juga dianggap berlebihan karena menganggap Al Masih sebagai anak Tuhan.

"Wahai Ahli Kitab, janganlah kamu melampaui batas dalam agamamu, dan janganlah kamu mengatakan terhadap Allah kecuali yang benar. Sesungguhnya Al Masih, Isa putra Maryam itu, adalah utusan Allah dan (yang diciptakan dengan) kalimat-Nya yang disampaikan-Nya kepada Maryam, dan (dengan tiupan) ruh dari-Nya. Maka berimanlah kamu kepada Allah dan rasul-rasul-Nya dan janganlah kamu mengatakan: '(Tuhan itu) tiga'. Berhentilah (dari ucapan itu). (Itu) lebih baik bagimu. Sesungguhnya Allah Tuhan Yang Maha Esa, Maha Suci Allah dari mempunyai anak, segala yang di langit dan di bumi adalah kepunyaan-Nya. Cukuplah Allah sebagai Pemelihara. Al Masih sekali-kali tidak enggan menjadi hamba bagi Allah dan tidak (pula enggan) malaikat-malaikat yang terdekat (kepada Allah). Barang siapa yang enggan dari menyembah-Nya dan menyombongkan diri, kelak Allah akan mengumpulkan mereka semua kepada-Nya." (Al Nisa: 171-172)

Di dalam Al Quran juga disebutkan bahwa Isa menyampaikan kabar kepada Bani Israil terkait dengan akan datangnya nabi terakhir, yaitu Nabi Muhammad.

“Dan (ingatlah) ketika Isa Putra Maryam berkata: 'Hai Bani Israil, sesungguhnya aku adalah utusan Allah kepadamu, membenarkan kitab (yang turun) sebelumku, yaitu Taurat dan memberi kabar gembira dengan (datangnya) seorang Rasul yang akan datang sesudahku, bernama Ahmad (Muhammad)'. Maka tatkala rasul itu datang kepada mereka dengan membawa bukti-bukti yang nyata, mereka berkata: 'Ini adalah sihir yang nyata". (AI Shaf: 6) 
Terkait dengan ajaran yang dibawa Isa AI Masih, Al Quran menyatakan bahwa ajaran Al Masih yang tertuang di dalam kitab Injil adalah ajaran yang benar, serta menganggapnya sebagai cahaya dan petunjuk.

“Dan Kami iringkan jejak mereka (nabi-nabi Bani Israil) dengan Isa putra Maryam, membenarkan kitab yang sebelumnya, yaitu: Taurat. Dan Kami telah memberikan kepadanya Kitab Injil sedang di dalamnya (ada) petunjuk dan cahaya (yang menerangi), dan membenarkan kitab yang sebelumnya, yaitu Kitab Taurat. Dan menjadi petunjuk serta pengajaran untuk orang-orang yang bertakwa." (Al Maidah: 46)

Di dalam ayat yang lain, Al Quran menegaskan bahwa siapa saja yang tidak menaati hukum hukum Allah yang ada di dalam Injil, ia jatuh dalam perilaku dosa.

"Dan hendaklah orang-orang pengikut Injil, memutuskan perkara menurut apa yang diturunkan Allah di dalamnya. Barangsiapa tidak memutuskan perkara menurut apa yang diturunkan Allah, maka mereka itu adalah orang-orang yang fasik." (Al Maidah: 47)

Nabi Isa adalah utusan Allah terakhir dari kalangan Bani Israil. la juga menjadi nabi terakhir sebelum diutusnya nabi yang membawa ajaran agama Islam, yaitu Nabi Muhammad. Keberadaan para Nabi mulia yang memiliki pertalian darah dengan umat Yahudi ini adalah citra positif yang ditunjukkan Al Quran terkait keunggulan umat Yahudi.

\section{Citra Buruk Bani Israil dalam AI Quran}

Teks-teks Al Quran secara umum menggambarkan Bani Israil (dan umat Yahudi) sebagai kaum yang buruk, yaitu sebagai entitas yang dimurkai oleh Allah. Semua ahli tafsir sepakat bahwa maksud dari frasa"yang dimurkai oleh Allah"yang terdapat pada surah Al Fatihah adalah orang-orang Yahudi (Syirazi, 1992: 7). Jadi, dalam pandangan umat Islam, Yahudi dan Israel adalah entitas yang dimurkai. Citra buruk tersebut semakin menebal karena adanya ayat-ayat lain dalam Al Quran yang menyebutkan sifat-sifat buruk mereka berikut ini.

\section{Tidak Memiliki Integritas}

Bani Israil memiliki citra sebagai orang-orang tidak memiliki integritas (tidak sesuai antara kata-kata dan perbuatan). Mereka menyuruh orang lain supaya berbuat kebaikan, tapi mereka sendiri tidak melakukan apa yang mereka ucapkan itu. 
"Mengapa kalian menyuruh orang lain (mengerjakan) kebajikan, sedangkan kalian melupakan diri (kewajiban) kalian sendiri, padahal kalian membaca Al Kitab (Taurat)? Maka tidakkah kalian berpikir?" (Al Baqarah: 44)

\section{Materialis}

Bani Israil memiliki citra sebagai orang yang materialis, yaitu orang-orang yang mencintai kehidupan dunia lebih dari bangsa manapun.

"Dan sungguh kamu akan mendapati mereka, manusia yang paling tamak kepada kehidupan (di dunia), bahkan (lebih tamak lagi) dari orang-orang musyrik. Masing-masing mereka ingin agar diberi umur seribu tahun, padahal umur panjang itu sekali-kali tidak akan menjauhkannya dari siksa. Allah Maha Mengetahui apa yang mereka kerjakan." (Al Baqarah: 96)

\section{Ingkar Janji}

Citra buruk lainnya yang melekat pada Bani Israil adalah sifat ingkar janji mereka. Jika mereka berjanji, dengan mudahnya mereka mengkhianati perjanjian itu.

"Patutkah (mereka ingkar kepada ayat-ayat Allah), dan setiap kali mereka mengikat janji, segolongan mereka melemparkannya?" (Al Baqarah: 100)

\section{Pembunuh Para Nabi}

Citra sebagai pembunuh orang-orang baik, yaitu para nabi yang diutus, melekat erat pada kaum Yahudi (Bani Israil).

Katakanlah: 'Mengapa kamu dahulu membunuh nabi-nabi Allah jika kamu benar-benar orang yang beriman?" (Al Baqarah: 91)

Citra sebagai pembunuh para nabi ini sangatlah negatif. Kaum Muslimin umumnya menggunakan penalaran yang sederhana untuk sampai kepada kesimpulan bahwa Bani Israil adalah orang-orang yang kejam. Kepada para nabi saja mereka sampai berani melakukan pembunuhan, apalagi kepada orang-orang biasa. Padahal, para nabi itu hadir di tengah-tengah mereka dengan menunjukkan sifatsifat kebaikannya; dan padahal, para nabi itu berasal dari sanak dan kaum kerabat mereka sendiri. 


\section{Rasis}

Bani Israil memiliki citra sebagai kelompok yang rasis. Mereka dicitrakan sebagai orang yang percaya bahwa mereka adalah ras yang unggul di dunia dan akhirat. Hanya karena mereka adalah keturunan Israil, mereka yakin bahwa merekalah penguasa dunia. Bahkan lebih dari itu, mereka juga percaya bahwa dengan keyahudian dan keisrailan mereka, nasib mereka di akhirat sudah terjamin sebagai penghuni surga.

“Katakanlah: 'Jika kalian (menganggap bahwa) rumah akhirat (surga) itu khusus untuk kalian di sisi Allah, bukan untuk orang lain, maka mohon segerakanlah kematian (kalian), jika kalian memang benar.

"Dan sekali-kali mereka tidak akan menginginkan kematian itu selama-lamanya, karena kesalahan-kesalahan yang telah diperbuat oleh tangan mereka (sendiri). Dan Allah Maha Mengetahui siapa orang yang zalim." (Al Baqarah: 94-95)

\section{Iri dan Dengki}

Di satu sisi, Bani Israil sangat bangga dan yakin dengan keunggulan ras mereka. Akan tetapi, di sisi lain, fakta menunjukkan bahwa sangat banyak umat lain yang dalam beberapa hal menunjukkan keunggulan dibandingkan kaum Yahudi. Adanya kesenjangan antara keyakinan dan fakta tersebut melahirkan sifat buruk lainnya yaitu iri dan dengki. Inilah citra buruk lain yang melekat pada Bani Israil.

"Orang-orang kafir dari Ahli Kitab dan orang-orang musyrik tiada menginginkan diturunkannya sesuatu kebaikan kepada kalian dari Tuhanmu. Dan Allah menentukan siapa yang dikehendaki-Nya (untuk diberi) rahmat-Nya; dan Allah mempunyai karunia yang besar." (Al Baqarah: 105)

\section{Jalan Tengah dalam Menyikapi Kaum Yahudi}

Dari berbagai pemaparan di atas terlihat bahwa ada dua model penggambaran yang ditunjukkan oleh Al Quran terkait dengan Bani Israil. Di satu sisi, AI Quran menggambarkan kaum Yahudi sebagai umat terpilih. Dari umat merekalah Allah mengutus banyak sekali nabi. Bahkan nabi-nabi terkemuka yang mampu menorehkan prestasi besar dalam sejarah peradaban dunia berasal dari Bani Israil. Nabi Ya'qub adalah Israil itu sendiri. Kemudian, ada nama Nabi Yusuf, Nabi Musa, Nabi Harun, Nabi Daud, Nabi Sulaiman, dan Nabi Isa. Mereka adalah nama-nama besar yang mustahil dihapus dari pentas sejarah peradaban dunia. 
Dalam pandangan Islam, para nabi yang berasal dari Bani Israil juga memiliki posisi yang sangat mulia. Mereka juga disebut sebagai nabi oleh orang-orang Islam. Seorang Muslim wajib beriman kepada para nabi itu, tidak peduli mereka berasal dari bangsa mana. Ibrahim, Ismail, Ishaq, Ya'qub, dan para nabi lainnya yang berasal dari keturunan Ya'qub (Bani Israil) adalah nama-nama yang sangat mulia dan dihormati oleh kaum Muslimin.

“Katakanlah: 'Kami beriman kepada Allah dan apa yang diturunkan kepada kami, dan apa yang diturunkan kepada Ibrahim, Isma'il, Ishaq, Ya'qub dan anak cucunya, dan apa yang diberikan kepada Musa dan Isa serta apa yang diberikan kepada nabi-nabi dari Tuhannya. Kami tidak membeda-bedakan seorangpun diantara mereka dan kami hanya tunduk patuh kepada-Nya". (Al Baqarah: 136) ${ }^{7}$

Dari sisi ini, citra Israel (Bani Israil) dalam pandangan kaum Muslimin bisa sangat positif. Akan tetapi, masih terkait dengan para nabi itu, AI Quran juga menggambarkan bagaimana reaksi buruk yang ditunjukkan oleh Bani Israil terhadap para nabi tersebut. Ditambah lagi dengan beberapa ayat AI Quran lainnya yang menggambarkan secara negatif Bani Israil dengan cara menyebutkan beberapa sifat buruk mereka.

Pembandingan kedua citra yang ditampilkan dalam Al Quran mengenai Bani Israil tersebut menunjukkan bahwa yang dikecam oleh Al Quran bukanlah keyahudian atau keisrailan mereka, melainkan adanya sifat-sifat buruk yang sudah mereka tunjukkan, dan yang tetap mereka pertahankan hingga sekarang. Al Quran tidak mengajarkan kebencian kepada Bani Israil (dan penganut agama Yahudi) atas dasar ras dan kelompok, karena justru salah satu yang dikecam oleh Al Quran dari Bani Israil itu adalah sifat rasis Bani Israil. Merupakan contradiction in terminis bila ada yang menyebutkan bahwa Islam bersikap rasis kepada Yahudi, padahal ayat Al Quran mengecam sikap rasis yang ditunjukkan kaum Yahudi. Prinsip AI Quran adalah mengecam rasisme, siapapun yang melakukannya.

\section{Kesimpulan}

Sebagai kitab suci yang juga memuat catatan sejarah, Al Quran banyak bercerita tentang Israel (Bani Israil). Bahkan, kisah tentang Bani Israil mendominasi bagian dari Al Quran yang memuat catatan sejarah. Di dalam Al Quran, Bani Israil disebut sebagai kaum terpilih karena banyak sekali nabi dan tokoh sejarah penting lainnya berasal dari kaum ini. Akan tetapi, kaum Yahudi dan Bani Israil juga digambarkan

$7 \quad$ Adanya perintah dalam teks Al Quran terkait dengan keharusan bagi seorang Muslim untuk mengimani dan memuliakan para nabi dari kalangan Bani Israil itu terdapat juga pada Al Baqarah: 285, Ali Imran: 84, dan Al Nisa: 152. 
sebagai kelompok yang banyak melakukan perbuatan buruk, termasuk di antaranya adalah pembangkangan, pengkhianatan, penyelewengan ajaran, bersikap rasis, serta pembunuhan terhadap para nabi yang diutus oleh Allah kepada mereka.

Dua model citra inilah yang menjadi landasan dua perspektif utama di kalangan internal umat Islam dalam menyikapi konflik Israel-Palestina, pertama yang menyatakan bahwa konflik ini adalah konflik agama Islam versus Yahudi, dan kedua yang menyatakan bahwa bukan agama yang menjadi akar konflik. Perspektif pertama dipengaruhi oleh ayat-ayat Al Quran yang menggambarkan orang-orang Yahudi sebagai umat yang bersifat amat buruk. Sebaliknya, perspektif kedua menggunakan ayat-ayat yang menggambarkan citra positif kaum Yahudi sebagai dasar pemikiran. Namun sebenarnya, kedua model citra ini tidaklah kontradiktif. Pujian Al Quran terhadap Bani Israil di satu sisi, dan kecaman atas sifat buruk mereka di sisi lain, menunjukkan bahwa secara teologis, kaum Muslimin tidak diperintahkan untuk membenci Yahudi (Israel) dengan alasan ras atau agama mereka, melainkan karena sifat-sifat mereka. Jika bangsa Israel meninggalkan sifat-sifat buruk tersebut, atau menghentikan penjajahan terhadap bangsa Palestina, tentu kaum Muslimin juga seharusnya meninggalkan kebencian tersebut.

\section{Daftar Pustaka}

Abdullah, T. (1982). Pemahaman Sejarah Indonesia, Sebelum dan Sesudah Revolusi. Jakarta: LP3ES.

Anshari, E. (1983). Wawasan Islam, Pokok-pokok Pikiran tentang Islam dan Umatnya. Bandung: PUSTAKA - Perpustakaan Salman ITB.

Departemen Agama RI. (2009). Al-Qur'an dan Tafsirnya. Jakarta: Depag RI.

Hanafi, A.(1984). Segi-Segi Kesusastraan pada Kisah-Kisah Al Quran. Jakarta: Pustaka Al-Husna.

Kartodirdjo, Sartono. (1984). Pemikiran dan Perkembangan Historiografi Indonesia, Suatu Alternatif. Jakarta: Gramedia.

Kashfi, J. (2016). Muhammad dan Kaum Yahudi. Jakarta: Titisan

Majid, A. (2013). Sejarah dalam AI Quran. [online] UPI. Dalam http://abdmajid.staf.upi. edu/2013/08/27/sejarah-dalam-alquran/ [Diakses 1 Juni 2018]

Naisābūri Al-, M. (2002). Al-Mustadrak 'alā Al-Sahīhain. Beirut: Dār Al-Kutub Al-'Ilmiyah. 
Qattan, M. (1992). Studi Ilmu-Ilmu Al-Qur'an (Terjemahan Mudzakir AS). Jakarta: Litera Antar Nusa.

Syirazi, N. (1992). Tafsir Al-Amtsal. Terjemahan Husein Alkaff dkk. Jakarta: Gerbang Ilmu Press. 